\title{
Discussion on the Construction of University Intelligent Campus under the Background of Big Data
}

\author{
Bo Chang \\ Xuzhou Technician Institute, Xuzhou 221151, China
}

\begin{abstract}
This paper focuses on the construction of the universities' intelligent campus, and analyzes its application under the background of big data. The core purpose is to build the intellectual campus, changing the current situation of single talent training, meet the basic needs of the construction data of the education system, to realize the stable innovation of the modern education system.
\end{abstract}

Keywords—big data; universities; intelligent campus; construction strategy

\section{INTRODUCTION}

At present, in the development of information technology, the teaching mode of higher education has changed. Most universities have established the prefect network, under development, and build abundant network resources. In order to improve the quality of teaching gradually, and to realize information management on educational system, universities have designed a relatively independent system of education management, and fully met the needs of the development of Education. But now in education integration, owing to lack of unity on the construction of intelligent campus in universities, there are many restrictions on education. Therefore, in its current stage of education system innovation, we should confirm the wisdom education system of universities, analyze the running status of big data, and integrate education system, so as to improve the overall effect of education effectively and meet the development needs of education.

\section{THE AIM OF THE CONSTRUCTION OF INTELLIGENT CAMPUS IN UNIVERSITIES}

\section{A. Data Standardization}

During the construction of intelligent campus in universities, its core is establish the campus business service center, by extracting, merging and screening the business data, a database of complete resources can be formed, in order to provide effective support for the resource optimization of the database. In addition, teachers and students through determine the unified standard of data, reduce the cost of project design and transform and explore the system, can get the data you need, so as to provide the support for the intelligent campus construction.

\section{B. Service Simplification}

It can be found, in the construction of intelligent campus, It can be used as the core of information management in universities, In this process, we should clear the thinking of management, analysis the management approach of sexually, make the information resources changed, realize one-stop service, and fully meet the needs of information service simplification .

in universities. Farther more, Students should play the main role with the dominance of teachers, and reacting to the information of teachers and students through a multidimensional management scheme.

\section{Task Correlation}

In the past, the construction of the information system in universities, the aim is to simplify the different kinds of business, and improve the work efficiency gradually. As the information manager integrating and developing the information resources, rarely thinking the status of the whole school. Construct the service platform, shows the integrated data, and for the relevant person provide abundant data resources, realizing effective query of the date. Teachers and students in universities can manage and analysis the data and resources comprehensive, according to different departments, in order to meet the needs of the construction intelligent campus fully.

\section{THE CHALlENGES FACING THE CONSTRUCTION OF UNIVERSITY INTELLIGENT CAMPUS UNDER BIG DATA}

\section{A. Lots of Date Resources, Disseminate the Educational Information is Difficult}

With the development of the big data, resource communication system in the network is larger. This factor limits the visibility of education resources. Found in the study, under the network background, there are several ways on publicize information, mainly including social media, enterprise production and sales, internet of things and sensors, government release, computer users, and so on. There are differences in use, because of the different sources of these information resources, they are restricting the visibility of educational information. Therefore, in this situation, we should recognize the problem in time, improving the visibility of educational information, by optimization treatment of information.

\section{B. Many Kinds of Information, Poor Effect of Education and Propaganda}

For many kinds of information, the range of communication, the speed of communication and the audience of the communication are different. In China, there is a relatively unitary phenomenon of information dissemination methods in universities, it leads to the educational information can not meet the needs of diversified development. For example, students view educational resources with their mobile 
phones, the course is complex. They use computer can make it easy. This is mainly due to education resources on mobile phones are less, and with other educational environment flooded, some educational resources are difficult to find in time.

\section{The Information is Fast and the Education Platform is Hard}

Under big data background, the diversified information data shows day after day. It makes the higher standards for the speed of data transmission and processing. Universities in the construction of information resources, channels of communication are narrow, the education network as the principal part, the collection of foreign media are less. It limits the information polling, and causes the information dissemination effectively.

\section{THE METHODS OF CONSTRUCTION OF UNIVERSITIES INTELLIGENT CAMPUS UNDER BIG DATA}

\section{A. Construction Process}

1) Big data sharing and communication platform: In big data sharing and platform designing, we should based on the construction of the original digital platform, consolidating information standards, and the interior lines of information system, design the management system effectively, to achieve the data exchange platform, make the data resources transform in operation system, and meet the needs of the resource sharing of the intelligent campus furthest. Not only under big data background, construct the intelligent campus, may achieve data access unifying, data decision and resource sharing, but by cloud computing, make resource sharing's dream comes true.

2) Identity management unifying: For the universities' intelligent campus platform, needs project the identity management and authentication system. By integrating network portal, authentication service, authorize, and office procedure, deal the authorities unified. Through the analysis of the process of user access, check and accept data resources, boost it innovate overall.

3) Personalized service system: In the construction of personalized service system, we should analysis the intelligent campus, build students', teachers' management system and assistant decision project, achieve inquire about Teachers' and students' affairs. To improve the value of information resources. Moreover, in the service center, we should according to the characteristics of university students, establish personalized, one-stop service institution, and open up the information resources effectively.

4) Mobile intelligent campus: For mobile intelligent campus, mainly includes apply internet technology, design intelligent network working platform, as shown in Figure 1. Teachers, students and universities can obtain real-time information query in this platform. Under this background, teachers may obtain massive information, deal with some related affairs in time. Students in this platform may obtain knowledge any time and any place, and can make full of your subjectivities, improve learning efficiency.

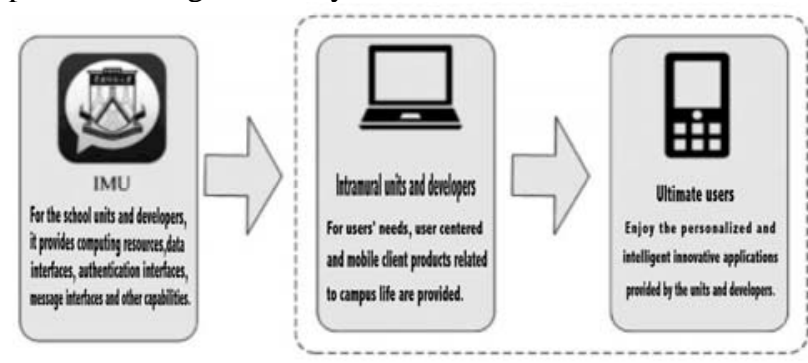

FIGURE I. THE DESIGN OF THE OPEN SYSTEM OF INTELLIGENT CAMPUS

5) Design of security system: In the design of university campus, owing to the plentiful of data information resources, we should explicit the importance of the design about the security system. We should plan the data system , confirm the security system, and analysis terminal equipment of security and personnel relationship. We ought to design security system, to ensure stability.

\section{B. Construct a Micro Platform for the Intelligent Campus for Universities}

In order to meet the needs and conform to the times, we should build micro platform, so as to meet the needs of different main part on the Intelligent campus platform. In general, in the design of micro platform, the following system forms should be built: first, the ability to open the platform. For the platform, it is mainly to build an open platform for information resources through the strength of the enterprise, the information on this platform, requires authorization management, universities provide unified identity authentication. Third party firm analyses user demands through open platform, build the feature service system. It is effective to make up for the shortage of information integration in universities. Second, the application service platform. We should design an application service platform, help the document to access, checkout the services cape, ask project application to complete system task detection in time, improve the quality of information services all-round. Third, the construct the micro service platform, for managers in universities, may review of micro service projects, configure and develop the resources, ensure the role about authority and interest, and bring about statistics and scientific analysis of data effective. Fourth, the design of the micro service supermarket. Through the review of the micro service system, students can add the information they need to the data list to meet the user's service needs.

\section{Construct a Big Data Platform for the Intelligent Campus for Universities}

The IT department in university needs to make a scientific integration of the collected data, and analyses of data results through the design of feedback system, so as to realize the real-time monitoring of the query process, improving the security of data storage and utilization. In this process, big data platforms can store data, can decision data, can analysis data. Accordingly, it's the core. 


\section{CONCLUSION}

In a word, nowadays, the construction of intelligent campus in universities, we should analysis the status of information integration ,design a scientific and systemized platform, according to the status, analysis the design process of the intelligent platform, analysis the design methods of micro platform, analysis big data platform, create an atmosphere, confirm conformable ways, increase of efficiency, promote the development.

\section{REFERENCE}

[1] Yang Changbin, Ouyang Peijin. Thinking on the construction of "intelligent campus" in Guizhou University from the perspective of big data strategy [J]. Journal of Caili University, 2016,34 (05): 143-147.

[2] Du Guozhen. Research on the construction of University intelligent campus under the background of big data, [J]. China new communication, 2016,18 (24): 25.

[3] Nie Wei. Research on the innovation of information construction of University intelligent campus under the view of big data [J]. information and computer information construction of intelligent campus data perspective (THEORY EDITION), 2017, (14): 120-121.

[4] Liu Yagang. Construction and Research on the intelligent campus service platform of private colleges and Universities under the large data environment, [J]. digital communication world, 2017, (08): 151.

[5] Zhou Lei. Research on the construction of University intelligent campus under the background of big data [J]. Chinese training, 2017, (17): 37-38. 